Volume. 8 Nomor. 1, Oktober 2020. p - 2354-8649 I e - 2579-5767

Open Access at: http:/ /ojs.umrah.ac.id/index.php/selat

DOI: https://doi.org/10.31629/selat.v8i1.2735

\title{
PENEGAKAN HUKUM TERHADAP KEBAKARAN HUTAN DI KABUPATEN PELALAWAN PROVINSI RIAU BERDASARKAN UNDANG-UNDANG NOMOR 41 TAHUN 1999 TENTANG KEHUTANAN
}

\author{
Andrew Shandy Utama1, Rizana ${ }^{2}$ \\ 1,2Fakultas Hukum Universitas Lancang Kuning \\ E-mail: 1andrew.fh.unilak@gmail.com, 2rizana@unilak.ac.id
}

\begin{abstract}
Forest fires are not a rare phenomenon in Indonesia, especially in Pelalawan Regency, Riau Province. In 2019 there was a forest fire in Pelalawan Regency covering an area of $827 \mathrm{Ha}$ and was directly visited by President Joko Widodo on September 17, 2019. This study aims to explain law enforcement against forest fires in Pelalawan Regency, Riau Province based on Law Number 41 of 1999 concerning Forestry. The method used in this research is sociological law research. Based on Article 50 paragraph (3) letter d of Law Number 41 Year 1999 concerning Forestry, it is stated that everyone is prohibited from burning forests. However, in 2019 there were forest fires in Pelalawan District covering an area of 827 hectares. The implementation of Law No. 41/1999 on Forestry against forest fires in Pelalawan District has not gone as expected. Burning forests is a criminal act. Law enforcement against the crime of forest burning in Pelalawan Regency, namely based on Article 78 paragraph (3) of Law Number 41 of 1999 concerning Forestry, it is stated that anyone who deliberately burns forests can be punished with imprisonment of up to 15 years and a maximum fine. IDR 5,000,000,000. The Pelalawan Regency Government can take preventive measures to minimize the occurrence of forest fires by carrying out legal counseling to the community regarding the prohibition of burning forests and increasing the role of the community in preserving the surrounding forests.
\end{abstract}

Keywords; Forest Burning, Crime, Law Enforcement

\begin{abstract}
Abstrak
Kebakaran hutan bukan merupakan fenomena yang langka di Indonesia, khususnya di Kabupaten Pelalawan Provinsi Riau. Pada tahun 2019 terjadi kebakaran hutan di Kabupaten Pelalawan seluas 827 Ha serta dikunjungi langsung oleh Presiden Joko Widodo pada tanggal 17 September 2019. Penelitian ini bertujuan untuk menjelaskan penegakan hukum terhadap kebakaran hutan di Kabupaten Pelalawan Provinsi Riau berdasarkan UndangUndang Nomor 41 Tahun 1999 tentang Kehutanan. Metode yang digunakan dalam penelitian ini adalah penelitian hukum sosiologis. Berdasarkan Pasal 50 ayat (3) huruf d Undang-Undang Nomor 41 Tahun 1999 tentang Kehutanan ditegaskan bahwa setiap orang dilarang membakar hutan. Akan tetapi, pada tahun 2019 terjadi kebakaran hutan di Kabupaten Pelalawan seluas 827 Ha.
\end{abstract}


Implementasi Undang-Undang Nomor 41 Tahun 1999 tentang Kehutanan terhadap kebakaran hutan di Kabupaten Pelalawan belum berjalan sesuai harapan. Membakar hutan merupakan tindak pidana. Penegakan hukum terhadap tindak pidana pembakaran hutan di Kabupaten Pelalawan yaitu berdasarkan pada Pasal 78 ayat (3) Undang-Undang Nomor 41 Tahun 1999 tentang Kehutanan ditegaskan bahwa barang siapa yang dengan sengaja membakar hutan dapat diancam dengan pidana penjara paling lama 15 tahun dan denda paling banyak Rp5.000.000.000,-. Pemerintah Kabupaten Pelalawan dapat melakukan upaya pencegahan untuk meminimalisir terjadinya kebakaran hutan dengan melaksanakan penyuluhan hukum ke tengah-tengah masyarakat mengenai larangan membakar hutan serta meningkatkan peran masyarakat dalam menjaga kelestarian hutan yang ada di sekitarnya.

Kata kuci; Pembakaran Hutan, Tindak Pidana, Penegakan Hukum

\section{PENDAHULUAN}

Hutan adalah suatu kesatuan ekosistem berupa hamparan lahan yang luas yang berisi sumber daya alam hayati yang didominasi oleh pepohonan dalam persekutuan alam lingkungannya yang tidak dapat dipisahkan antara yang satu dengan yang lainnya. ${ }^{1}$ Dasar hukum yang mengatur mengenai hutan di Indonesia adalah UndangUndang Nomor 41 Tahun 1999 tentang Kehutanan.

Hutan sebagai karunia dan amanah dari Tuhan Yang Maha Esa yang dianugerahkan kepada bangsa Indonesia merupakan kekayaan alam yang tidak ternilai harganya. Hutan merupakan unsur utama sistem penyangga kehidupan manusia dan merupakan modal dasar pembangunan nasional yang memiliki manfaat nyata, baik manfaat ekologi, manfaat sosial budaya, maupun manfaat ekonomi. Oleh karena itu, pemanfaataan dan penggunaannya harus dilakukan secara terencana, rasional, optimal, dan bertanggung jawab sesuai dengan kemampuan daya dukung serta memperhatikan kelestarian fungsi dan keseimbangan lingkungan hidup untuk mendukung pengelolaan hutan dan pembangunan kehutanan yang berkelanjutan bagi kemakmuran rakyat. Hal ini sejalan dengan ketentuan Undang-Undang Dasar Negara Republik Indonesia Tahun 1945 (Salim H.S., 2013). ${ }^{2}$

Pasal 33 ayat (3) Undang-Undang Dasar Negara Republik Indonesia Tahun 1945 mengamanatkan bahwa bumi, air, dan kekayaan alam yang terkandung di

\footnotetext{
${ }^{1}$ Supriadi. Hukum Kehutanan dan Hukum Perkebunan di Indonesia. Jakarta: Sinar Grafika, 2010, hlm. 25.

2 Salim HS. Dasar-dasar Hukum Kehutanan. Jakarta: Sinar Grafika, 2013, hlm. 7.
} 
dalamnya dikuasai oleh negara dan dipergunakan untuk sebesar-besarnya kemakmuran rakyat. ${ }^{3}$

Dalam rangka memperoleh manfaat yang optimal dari hutan dan kawasan hutan bagi kesejahteraan masyarakat, maka pada prinsipnya semua hutan dan kawasan hutan dapat dimanfaatkan dengan memperhatikan sifat, karakteristik, dan kerentaannya, serta tidak dibenarkan mengubah fungsi pokoknya, yaitu fungsi konservasi, fungsi lindung, dan fungsi produksi. Untuk menjaga keberlangsungan fungsi pokok hutan dan kondisi hutan, dilakukan juga upaya rehabilitasi serta reklamasi hutan yang bertujuan untuk mengembalikan kelestarian hutan. ${ }^{4}$

Pada Pasal 6 Undang-Undang Nomor 41 Tahun 1999 tentang Kehutanan disebutkan bahwa hutan mempunyai tiga fungsi, yaitu fungsi konservasi, fungsi lindung, dan fungsi produksi. Oleh karena itu, pemerintah kemudian menetapkan tiga jenis hutan berdasarkan fungsinya, yaitu Hutan Konservasi, Hutan Lindung, dan Hutan Produksi. ${ }^{5}$

Penguasaan hutan dan sumber daya alam yang ada di dalamnya oleh negara memberikan kewenangan kepada pemerintah untuk mengatur dan mengurus segala sesuatu yang berkaitan dengan hutan, kawasan hutan, dan hasil hutan. Pemerintah juga berwenang menetapkan kawasan hutan dan/atau mengubah status kawasan hutan. Selain itu, pemerintah juga berwenang mengatur dan menetapkan hubungan hukum antara orang dan hutan atau kawasan hutan dan hasil hutan. Terakhir, pemerintah juga diberikan kewenangan untuk mengatur perbuatan hukum mengenai kehutanan. ${ }^{6}$

Jadi, penguasaan hutan oleh negara bukan merupakan pemilikan, tetapi negara memberikan kewenangan kepada pemerintah untuk mengatur dan mengurus segala sesuatu yang berkaitan dengan hutan, kawasan hutan, dan hasil hutan. Pemerintah berwenang untuk memberikan izin kepada pihak lain untuk melakukan kegiatan di bidang kehutanan. Pemanfaatan hutan dilakukan dengan pemberian izin pemanfaatan kawasan, izin pemanfaatan jasa lingkungan, izin pemanfaatan hasil

\footnotetext{
3 Pasal 33 ayat (3) Undang-Undang Dasar Negara Republik Indonesia Tahun 1945.

${ }^{4}$ Abdul Muis Yusuf dan Mohammad Taufik Makarao. Hukum Kehutanan di Indonesia. Jakarta: Rineka Cipta, 2011, hlm. 10 .

5 Pasal 6 Undang-Undang Nomor 41 Tahun 1999 tentang Kehutanan.

${ }^{6}$ Salim HS. Dasar-dasar... Op. Cit., hlm. 13.
} 
hutan kayu dan izin pemanfaatan hasil hutan bukan kayu, serta izin pemungutan hasil hutan kayu dan bukan kayu. ${ }^{7}$

Berdasarkan Pasal 50 ayat (3) huruf d Undang-Undang Nomor 41 Tahun 1999 tentang Kehutanan ditegaskan bahwa setiap orang dilarang membakar hutan. ${ }^{8}$ Kebakaran hutan bukan merupakan fenomena yang langka di Indonesia, khususnya di Kabupaten Pelalawan Provinsi Riau. Setiap tahun rutin terjadi kebakaran hutan di Kabupaten Pelalawan. Hutan yang terbakar mengakibatkan polusi udara berupa kabut asap yang dapat merusak kesehatan, bahkan kabut asap tersebut menyebar hingga ke Malaysia dan Singapura. Berdasarkan studi kepustakaan penelitian yang dilakukan, peneliti memperoleh data dari Badan Nasional Penanggulangan Bencana (BNPB) Provinsi Riau bahwa pada tahun 2019 terjadi kebakaran hutan di Kabupaten Pelalawan seluas 827 Ha dan dikunjungi langsung oleh Presiden Joko Widodo pada tanggal 17 September 2019.

Dari latar belakang masalah yang telah dijelaskan di atas, maka rumusan masalah yang dibahas dalam penelitian ini adalah sebagai berikut:

1. Bagaimanakah penegakan hukum terhadap kebakaran hutan di Kabupaten Pelalawan Provinsi Riau berdasarkan Undang-Undang Nomor 41 Tahun 1999 tentang Kehutanan?

2. Apakah faktor-faktor yang menghambat dalam penegakan hukum terhadap kebakaran hutan di Kabupaten Pelalawan Provinsi Riau?

3. Bagaimanakah upaya yang dilakukan untuk mengatasi faktor-faktor yang menghambat dalam penegakan hukum terhadap kebakaran hutan di Kabupaten Pelalawan Provinsi Riau berdasarkan Undang-Undang Nomor 41 Tahun 1999 tentang Kehutanan?

Kabupaten Pelalawan sejarahnya berasal dari sebuah kerajaan yang bernama Kerajaan Pekantua. Kerajaan Pekantua didirikan oleh seorang bangsawan dari Kerajaan Temasik (Singapura) yang bernama Maharaja Indera pada tahun 1380 di Pematang Tuo yang terletak di tepi Sungai Pekantua, yang merupakan anak dari Sungai Kampar. Maharaja Indera memerintah Kerajaan Pekantua dari tahun 1380 sampai tahun 1420. Pada tahun 1505, dalam upacara pengangkatan Munawar Syah

\footnotetext{
7 Ibid., hlm. 14-15.

8 Pasal 50 ayat (3) huruf d Undang-Undang Nomor 41 Tahun 1999 tentang Kehutanan.
} 
sebagai raja Kerajaan Pekantua, diumumkan perubahan nama Kerajaan Pekantua menjadi Kerajaan Pekantua Kampar dan bergabung di bawah kekuasaan Kerajaan Melaka (Malaysia). Pada masa pemerintahan Maharaja Dinda II tahun 1725 dilakukan pemindahan pusat Kerajaan Pekantua Kampar dari Pematang Tuo ke Sungai Rasau yang terletak di hilir Sungai Nilo serta disepakati perubahan nama Kerajaan Pekantua Kampar menjadi Kerajaan Pelalawan.

Pada tahun 1797, Kerajaan Siak Sri Indrapura di bawah kepemimpinan Sultan Syarif Ali bin Sayyid Usman Assegaf menyerang Kerajaan Pelalawan dan berhasil menaklukkannya di bawah kekuasaan Kerajaan Siak Sri Indrapura. Raja terakhir yang diutus oleh Kerajaan Siak Sri Indrapura untuk memimpin Kerajaan Pelalawan adalah Tengku Said Harun Assegaf yang memerintah dari tahun 1941 sampai tahun 1945. Setelah kemerdekaan Republik Indonesia diproklamasikan pada tanggal 17 Agustus 1945, Kerajaan Siak Sri Indrapura beserta seluruh daerah kekuasaannya bergabung menjadi bagian dari Republik Indonesia.

Pada tahun 1999, Pelalawan dimekarkan dari Kabupaten Kampar Provinsi Riau menjadi sebuah kabupaten yang otonom seluas $12.758 \mathrm{Km}^{2}$ serta terdiri atas empat kecamatan, yaitu Kecamatan Langgam, Kecamatan Pangkalan Kuras, Kecamatan Bunut, dan Kecamatan Kuala Kampar. Adapun mata pencarian masyarakat Kabupaten Pelalawan sebagian besar adalah sebagai petani perkebunan kelapa sawit.

\section{METODE PENELITIAN}

Penelitian hukum adalah suatu kegiatan ilmiah yang didasarkan pada metode, sistematika, dan pemikiran tertentu yang bertujuan untuk mempelajari satu atau beberapa gejala hukum tertentu dengan jalan menganalisanya. ${ }^{9}$ Metode yang digunakan dalam penelitian ini adalah penelitian hukum sosiologis. Penelitian hukum sosiologis adalah suatu penelitian yang dilakukan dengan cara menjelaskan pelaksanaan peraturan perundang-undangan terhadap permasalahan yang ada di masyarakat. ${ }^{10}$ Sumber data yang digunakan dalam penelitian ini adalah data primer dan data sekunder. Data primer yaitu data yang diperoleh langsung dari hasil observasi, wawancara, dan kuisioner di lokasi penelitian; sedangkan data sekunder

\footnotetext{
${ }_{9}^{9}$ Soerjono Soekanto. Pengantar Penelitian Hukum. Jakarta: UI Press, 2007, hlm. 40.

10 Zainuddin Ali. Metode Penelitian Hukum. Jakarta: Sinar Grafika, 2013, hlm. 75.
} 
yaitu data yang diperoleh dari jurnal-jurnal ilmiah, literatur hukum, dan peraturan perundang-undangan. Teknik pengumpulan data yang digunakan dalam penelitian ini adalah observasi, wawancara, dan studi kepustakaan. Teknik analisis data yang digunakan dalam penelitian ini adalah analisis kualitatif.

\section{PEMBAHASAN}

Berdasarkan Pasal 1 huruf b Undang-Undang Nomor 41 Tahun 1999 tentang Kehutanan dijelaskan bahwa hutan adalah suatu kesatuan ekosistem berupa hamparan lahan yang luas yang berisi sumber daya alam hayati yang didominasi oleh pepohonan dalam persekutuan alam lingkungannya yang tidak dapat dipisahkan antara yang satu dengan yang lainnya. ${ }^{11}$ Asas-asas dalam penyelenggaraan kehutanan di Indonesia sebagaimana yang diatur dalam Undang-Undang Nomor 41 Tahun 1999 tentang Kehutanan yaitu sebagai berikut:

1. Asas Manfaat dan Lestari

Penyelenggaraan kehutanan berasaskan manfaat dan lestari dimaksudkan agar setiap pelaksanaan penyelenggaraan kehutanan memperhatikan keseimbangan dan kelestarian unsur lingkungan, sosial, budaya, dan ekonomi.

2. Asas Kerakyatan dan Keadilan

Penyelenggaraan kehutanan berasaskan kerakyatan dan keadilan dimaksudkan agar setiap penyelenggaraan kehutanan harus memberikan peluang dan kesempatan yang sama kepada semua warga negara sesuai dengan kemampuannya, sehingga dapat meningkatkan kemakmuran seluruh rakyat.

3. Asas Kebersamaan

Penyelenggaranaan kehutanan berasaskan kebersamaan dimaksudkan agar dalam penyelenggaraan kehutanan menerapkan pola usaha bersama, sehingga terjalin saling keterkaitan dan saling ketergantungan secara sinergis antara masyarakat setempat dengan BUMN atau BUMD dan BUMS di Indonesia dalam rangka pemberdayaan usaha kecil, menengah, dan koperasi.

4. Asas

Keterbukaan

11 Pasal 1 huruf b Undang-Undang Nomor 41 Tahun 1999 tentang Kehutanan. 
Penyelenggaraan kehutanan berasaskan keterbukaan dimaksudkan agar setiap kegiatan penyelenggaraan kehutanan mengikutsertakan masyarakat dan memperhatikan aspirasi masyarakat.

5. Asas Keterpaduan

Penyelenggaraan kehutanan berasaskan keterpaduan dimaksudkan agar setiap penyelenggaraan kehutanan dilakukan secara terpadu dengan memperhatikan kepentingan nasional, sektor lain, dan masyarakat setempat. ${ }^{12}$

Undang-Undang Nomor 41 Tahun 1999 tentang Kehutanan menyebutkan bahwa penyelenggaraan kehutanan di Indonesia bertujuan untuk sebesar-besar kemakmuran rakyat yang berkeadilan dan berkelanjutan dengan:

1. Menjamin keberadaan hutan dengan luasan yang cukup dan sebaran yang proporsional.

2. Mengoptimalkan aneka fungsi hutan, yang meliputi fungsi konservasi, fungsi lindung, dan fungsi produksi untuk mencapai manfaat lingkungan, sosial, budaya, dan ekonomi yang seimbang dan lestari.

3. Meningkatkan daya dukung daerah aliran sungai.

4. Meningkatkan kemampuan untuk mengembangkan kapasitas dan keberdayaan masyarakat secara partisipatif, berkeadilan, dan berwawasan lingkungan, sehingga mampu menciptakan ketahanan sosial dan ekonomi serta ketahanan terhadap akibat perubahan eksternal.

5. Menjamin distribusi manfaat yang berkeadilan dan berkelanjutan. ${ }^{13}$

Hutan merupakan salah satu kekayaan sumber daya alam bangsa Indonesia yang dapat dimanfaatkan dalam kehidupan sehari-hari. Oleh karena itu, hutan harus dijaga kelestariannya agar dapat diwariskan dari generasi ke generasi. Sejalan dengan itu, menurut Pasal 50 ayat (3) huruf d Undang-Undang Nomor 41 Tahun 1999 tentang Kehutanan ditegaskan bahwa setiap orang dilarang membakar hutan. ${ }^{14}$ Ketentuan tersebut dapat diartikan bahwa meskipun hutan dapat dimanfaatkan dalam kehidupan sehari-hari, tetapi setiap orang dilarang membakar hutan untuk memperoleh manfaatnya dengan tujuan agar kelestarian hutan tetap terjaga.

\footnotetext{
12 Pasal 2 Undang-Undang Nomor 41 Tahun 1999 tentang Kehutanan.

13 Pasal 3 Undang-Undang Nomor 41 Tahun 1999 tentang Kehutanan.

14 Pasal 50 ayat (3) huruf d Undang-Undang Nomor 41 Tahun 1999 tentang Kehutanan.
} 
Penegakan hukum terhadap kebakaran hutan di Kabupaten Pelalawan Provinsi Riau berdasarkan Undang-Undang Nomor 41 Tahun 1999 tentang Kehutanan belum terlaksana sesuai dengan harapan. Meskipun setiap orang dilarang membakar hutan, namun ternyata setiap tahun rutin terjadi kebakaran hutan di Kabupaten Pelalawan. Data dari Badan Nasional Penanggulangan Bencana (BNPB) Provinsi Riau menyebutkan bahwa pada tahun 2019 terjadi kebakaran hutan di Kabupaten Pelalawan seluas 827 Ha. Peraturan perundang-undangan di Indonesia sebenarnya ada mengecualikan bahwa perbuatan membakar hutan dibolehkan dengan mempertimbangkan kearifan lokal. ${ }^{15}$

Kapabilitas Pemerintah Provinsi Riau dalam mengendalikan kebakaran hutan belum optimal karena kebijakan Pemerintah Provinsi Riau hanya diarahkan pada proses pemadaman terhadap hutan yang terbakar. Pemerintah Provinsi Riau sampai saat ini belum menemukan solusi yang ideal untuk mencegah kebakaran hutan yang rutin terjadi setiap tahun. Selain itu, alokasi anggaran dana yang disediakan untuk penanganan kebakaran hutan jumlahnya terbatas sehingga Pemerintah Provinsi Riau harus menunggu bantuan dana dan peralatan teknis dari pemerintah pusat. Dengan hamparan hutan gambut yang luas, Pemerintah Provinsi Riau seharusnya mengalokasikan anggaran dana yang besar untuk mengantisipasi terjadinya kebakaran hutan, khususnya pada musim kemarau. ${ }^{16}$

Faktor yang menghambat dalam penegakan hukum terhadap kebakaran hutan di Kabupaten Pelalawan Provinsi Riau yang pertama adalah masih minimnya pemahaman masyarakat mengenai manfaat hutan untuk jangka panjang. Sebagian besar masyarakat hanya beranggapan bahwa hutan merupakan salah satu kekayaan sumber daya alam yang harus dikelola untuk meningkatkan perekonomiannya pada saat itu saja, tanpa mempertimbangkan bahwa hutan merupakan paru-paru dunia sebagai penghasil udara segar yang baik untuk kesehatan manusia dan berguna untuk menyeimbangkan keadaan iklim global, sehingga hutan harus dijaga kelestariannya dan diwariskan untuk generasi berikutnya.

\footnotetext{
15 Hendra Eriant Dikser, Erdianto, dan Widia Edorita. “Analisis Yuridis terhadap Pengecualian Pembakaran Lahan dan Hutan Berdasarkan Pasal 69 ayat (2) Undang-Undang Nomor 32 Tahun 2009 tentang Perlindungan dan Pengelolaan Lingkungan Hidup". Jurnal Online Mahasiswa (JOM) Fakultas Hukum Universitas Riau, 2017: Vol. IV, No. 2, hlm. 15.

${ }^{16}$ Geovani Meiwanda. "Kapabilitas Pemerintah Daerah Provinsi Riau; Hambatan dan Tantangan Pengendalian Kebakaran Hutan dan Lahan”. Jurnal Sosial Politik, 2016: Vol. 19, No. 3, hlm. 160-261.
} 
Faktor yang menghambat dalam penegakan hukum terhadap kebakaran hutan di Kabupaten Pelalawan Provinsi Riau yang kedua adalah masih lemahnya penegakan hukum terhadap pelaku tindak pidana pembakaran hutan. Meskipun pada Pasal 50 ayat (3) huruf d Undang-Undang Nomor 41 Tahun 1999 tentang Kehutanan ditegaskan bahwa setiap orang dilarang membakar hutan, ternyata setiap tahun rutin terjadi kebakaran hutan di Kabupaten Pelalawan.

Membakar hutan merupakan tindak pidana, sehingga dalam Undang-Undang Nomor 41 Tahun 1999 tentang Kehutanan diatur mengenai sanksi pidana yang tegas bagi siapa saja yang melakukan tindak pidana pembakaran hutan. ${ }^{17}$ Dalam rangka mewujudkan efektivitas penegakan hukum terhadap kebakaran hutan di Kabupaten Pelalawan Provinsi Riau, dibutuhkan adanya penegakan hukum yang tegas terhadap siapa saja yang melakukan tindak pidana pembakaran hutan. Akan tetapi, penegakan hukum tidak dapat berjalan sebagaimana yang dicita-citakan karena terdapat faktorfaktor yang mempengaruhi proses penegakan hukum.

Menurut Lawrence M. Friedman, efektivitas dalam penegakan hukum dipengaruhi oleh struktur hukum, substansi hukum, dan budaya hukum. Lawrence M. Friedman mengartikan struktur hukum yaitu aparatur penegak hukum yang menjalankan proses penegakan hukum, seperti polisi, jaksa, dan hakim. Substansi hukum diartikan oleh Lawrence M. Friedman yaitu isi dari peraturan perundangundangan yang berlaku. Selain itu, Lawrence M. Friedman menjelaskan bahwa budaya hukum merupakan kebiasaan-kebiasaan yang ada di tengah-tengah kelompok masyarakat tertentu yang diwariskan dari generasi ke generasi dan dipatuhi oleh masyarakat. 18

Sejalan dengan itu, Soerjono Soekanto menyebutkan bahwa faktor-faktor yang mempengaruhi penegakan hukum ada lima, yaitu faktor hukum itu sendiri (undangundang), faktor penegak hukum, faktor sarana yang mendukung penegakan hukum, faktor masyarakat, dan faktor kebudayaan. Kelima faktor tersebut saling berkaitan erat karena merupakan esensi dari penegakan hukum dan tolak ukur dari efektivitas penegakan hukum. ${ }^{19}$

17 Wartiningsih. Pidana Kehutanan; Keterlibatan dan Pertanggungjawaban Penyelenggara Kebijakan Kehutanan. Malang: Setara Press, 2014, hlm. 46.

${ }^{18}$ Lawrence M. Friedman. Sistem Hukum; Perspektif Ilmu Sosial. Bandung: Nusa Media, 2009, hlm. 63.

19 Soerjono Soekanto. Faktor-faktor yang Mempengaruhi Penegakan Hukum. Jakarta: Rajawali Pers, 2013, hlm. 8-9. 
Upaya yang dilakukan oleh Pemerintah Kabupaten Pelalawan untuk mengatasi minimnya pemahaman masyarakat Kabupaten Pelalawan mengenai manfaat hutan untuk jangka panjang adalah Pemerintah Kabupaten Pelalawan dapat melaksanakan penyuluhan hukum ke tengah-tengah masyarakat mengenai larangan membakar hutan berdasarkan Undang-Undang Nomor 41 Tahun 1999 tentang Kehutanan, sanksi pidana bagi pelaku tindak pidana pembakaran hutan, serta bahaya kebakaran hutan bagi kehidupan. Agar program penyuluhan hukum ke tengah-tengah masyarakat tersebut lebih efektif, Pemerintah Kabupaten Pelalawan sebaiknya bekerja sama dengan pihak Kepolisian Resort Pelalawan dalam memberikan penyuluhan hukum kepada masyarakat. Penguatan peran pihak kepolisian tersebut secara psikologis dapat meyakinkan masyarakat bahwa membakar hutan merupakan tindak pidana. ${ }^{20}$

Selain itu, upaya yang dilakukan oleh Pemerintah Kabupaten Pelalawan untuk mengatasi minimnya pemahaman masyarakat Kabupaten Pelalawan mengenai manfaat hutan untuk jangka panjang adalah Pemerintah Kabupaten Pelalawan dapat meningkatkan peran masyarakat dalam menjaga kelestarian hutan yang ada di sekitarnya. Berdasarkan Undang-Undang Nomor 41 Tahun 1999 tentang Kehutanan disebutkan bahwa masyarakat berkewajiban untuk ikut memelihara dan menjaga hutan dari gangguan dan perusakan yang dilakukan oleh orang-orang yang tidak bertanggung jawab.21 Salah satu bentuk peningkatan peran masyarakat untuk menjaga kelestarian hutan yaitu adanya penghargaan dari Pemerintah Kabupaten Pelalawan kepada masyarakat, baik perorangan maupun kelompok masyarakat, apabila mengetahui dan melaporkan pelaku pembakaran hutan.

Sanksi hukum terhadap pelaku tindak pidana pembakaran hutan di Kabupaten Pelalawan berdasarkan Pasal 78 ayat (3) Undang-Undang Nomor 41 Tahun 1999 tentang Kehutanan adalah bahwa barang siapa yang dengan sengaja membakar hutan dapat diancam dengan pidana penjara paling lama 15 (lima belas) tahun dan denda paling banyak Rp5.000.000.000,- (lima miliar rupuah). ${ }^{22}$

\footnotetext{
${ }^{20}$ Andrew Shandy Utama. "Kepercayaan Masyarakat terhadap Penegakan Hukum di Indonesia". Jurnal Ensiklopedia Social Review, 2019: Vol. 1, No. 3, hlm. 313.

${ }^{21}$ Andrew Shandy Utama dan Rizana. "Penegakan Hukum terhadap Kebakaran Hutan dan Lahan di Kabupaten Indragiri Hilir". Jurnal The Juris, 2020: Vol. IV, No. 1, hlm. 37-38.

22 Pasal 78 ayat (3) Undang-Undang Nomor 41 Tahun 1999 tentang Kehutanan.
} 
Selanjutnya, pada Pasal 78 ayat (4) Undang-Undang Nomor 41 Tahun 1999 tentang Kehutanan ditegaskan bahwa barang siapa yang karena kelalaiannya menyebabkan hutan terbakar dapat diancam dengan pidana penjara paling lama 5 (lima) tahun dan denda paling banyak Rp1.500.000.000,- (satu miliah lima ratus juta rupiah). ${ }^{23}$

Sanksi hukum apabila tindak pidana pembakaran hutan di Kabupaten Pelalawan dilakukan oleh badan hukum atau badan usaha dan/atau atas nama badan hukum atau badan usaha, maka tuntutan pidananya akan dijatuhkan kepada pengurus badan hukum atau badan usaha tersebut dengan sanksi pidana sebagaimana yang telah ditegaskan pada Pasal 78 ayat (3) Undang-Undang Nomor 41 Tahun 1999 tentang Kehutanan di atas, lalu sanksi pidananya ditambah dengan 1/3 (sepertiga) dari sanksi pidana pada Pasal 78 ayat (3) Undang-Undang Nomor 41 Tahun 1999 tentang Kehutanan tersebut.

Apabila tindak pidana pembakaran hutan dilakukan oleh badan hukum atau badan usaha dan/atau atas nama badan hukum atau badan usaha, maka Kepolisian Resort Pelalawan dapat menggunakan prinsip strict liability, yaitu pertanggungjawaban dari pelaku tindak pidana atas kejahatan yang telah dilakukannya. Prinsip strict liability pernah diterapkan oleh hakim pada putusan terhadap kasus tindak pidana pembakaran hutan di Provinsi Riau yang dilakukan oleh PT Adei Plantation pada tahun 2014.24

\section{PENUTUP}

\subsection{Simpulan}

Berdasarkan Pasal 50 ayat (3) huruf d Undang-Undang Nomor 41 Tahun 1999 tentang Kehutanan ditegaskan bahwa setiap orang dilarang membakar hutan. Akan tetapi, pada tahun 2019 terjadi kebakaran hutan di Kabupaten Pelalawan seluas 827 Ha. Penegakan hukum terhadap kebakaran hutan di Kabupaten Pelalawan Provinsi Riau berdasarkan Undang-Undang Nomor 41 Tahun 1999 tentang Kehutanan belum terlaksana sesuai dengan harapan. Faktor yang menghambat dalam penegakan

23 Pasal 78 ayat (4) Undang-Undang Nomor 41 Tahun 1999 tentang Kehutanan.

${ }^{24}$ Eko Ardiansyah Pandiangan, Erdianto, dan Ledy Diana. "Penerapan Prinsip Strict Liability dalam Pertanggungjawaban Korporasi yang Dianggap Bertanggung Jawab atas Kebakaran Hutan di Provinsi Riau". Jurnal Online Mahasiswa (JOM) Fakultas Hukum Universitas Riau, 2016: Vol. III, No. 2, hlm. 15. 
hukum terhadap kebakaran hutan di Kabupaten Pelalawan Provinsi Riau adalah masih minimnya pemahaman masyarakat mengenai manfaat hutan untuk jangka panjang serta masih lemahnya penegakan hukum terhadap pelaku tindak pidana pembakaran hutan. Pemerintah Kabupaten Pelalawan dapat melaksanakan penyuluhan hukum ke tengah-tengah masyarakat mengenai larangan membakar hutan berdasarkan Undang-Undang Nomor 41 Tahun 1999 tentang Kehutanan, sanksi pidana bagi pelaku tindak pidana pembakaran hutan, serta bahaya kebakaran hutan bagi kehidupan. Selain itu, Pemerintah Kabupaten Pelalawan dapat meningkatkan peran masyarakat dalam menjaga kelestarian hutan yang ada di sekitarnya.

\subsection{Saran}

Pemerintah Kabupaten Pelalawan sebaiknya bekerja sama dengan Kepolisian Resort

Pelalawan dan instansi terkait lainnya dalam mencegah kebakaran hutan di Kabupaten Pelalawan.

\section{DAFTAR PUSTAKA}

\section{Buku}

Ali, Zainuddin. Metode Penelitian Hukum. Jakarta: Sinar Grafika, 2013.

Friedman, Lawrence M. Sistem Hukum; Perspektif Ilmu Sosial. Bandung: Nusa Media, 2009.

HS, Salim. Dasar-dasar Hukum Kehutanan. Jakarta: Sinar Grafika, 2013.

Soekanto, Soerjono. Pengantar Penelitian Hukum. Jakarta: UI Press, 2007.

Soekanto, Soerjono. Faktor-faktor yang Mempengaruhi Penegakan Hukum. Jakarta: Rajawali Pers, 2013.

Supriadi. Hukum Kehutanan dan Hukum Perkebunan di Indonesia. Jakarta: Sinar Grafika, 2010.

Wartiningsih. Pidana Kehutanan; Keterlibatan dan Pertanggungjawaban Penyelenggara Kebijakan Kehutanan. Malang: Setara Press, 2014.

Yusuf, Abdul Muis Yusuf Mohammad Taufik Makarao. Hukum Kehutanan di Indonesia. Jakarta: Rineka Cipta, 2011. 


\section{Artikel}

Dikser, Hendra Eriant, Erdianto, dan Widia Edorita. "Analisis Yuridis terhadap Pengecualian Pembakaran Lahan dan Hutan Berdasarkan Pasal 69 Ayat (2) Undang-Undang Nomor 32 Tahun 2009 tentang Perlindungan dan Pengelolaan Lingkungan Hidup". Jurnal Online Mahasiswa (JOM) Fakultas Hukum Universitas Riau, 2017: Volume IV, Nomor 2.

Meiwanda, Geovani. "Kapabilitas Pemerintah Daerah Provinsi Riau; Hambatan dan Tantangan Pengendalian Kebakaran Hutan dan Lahan". Jurnal Sosial Politik, 2016: Volume 19, Nomor 3.

Pandiangan, Eko Ardiansyah, Erdianto, dan Ledy Diana. "Penerapan Prinsip Strict Liability dalam Pertanggungjawaban Korporasi yang Dianggap Bertanggung Jawab atas Kebakaran Hutan di Provinsi Riau". Jurnal Online Mahasiswa (JOM) Fakultas Hukum Universitas Riau, 2016: Volume III, Nomor 2.

Utama, Andrew Shandy. "Kepercayaan Masyarakat terhadap Penegakan Hukum di Indonesia”. Jurnal Ensiklopedia Social Review, 2019: Volume 1, Nomor 3.

Utama, Andrew Shandy dan Rizana. "Penegakan Hukum terhadap Kebakaran Hutan dan Lahan di Kabupaten Indragiri Hilir". Jurnal The Juris, 2020: Volume IV, Nomor 1.

\section{Peraturan Perundang-undangan}

Undang-Undang Nomor 41 Tahun 1999 tentang Kehutanan. Lembaran Negara Republik Indonesia Tahun 1999 Nomor 167, Tambahan Lembaran Negara Republik Indonesia Nomor 3888. 